\title{
MODEL PEMBELAJARAN BAHASA ARAB DI SMPUT BUMI KARTINI DALAM MENINGKATKAN KEMAMPUAN SISWA BERBAHASA ARAB
}

\author{
${ }^{1}$ Ana Rahmawati, ${ }^{2}$ Azzah Nor Laila \\ ${ }^{1,2}$ Staff Pengajar di UNISNU Jepara \\ 1bundacacajpr@gmail.com \\ ªzzahdzulqarnain@gmail.com
}

\begin{abstract}
This study aims to describe the Arabic learning model in SMP Kartini Bumi in an effort to improve the ability of Arabic-speaking students, besides that this study also attempts to explain some of the inhibiting factors and factors that support the implementation of intensive Arabic language programs (extracurricular activities) carried out in the boarding environment school in the Bumi Kartinid SMPUT in an effort to improve the ability of the Arabic language students in addition to the Arabic subjects that they actually get in learning in the classroom as subjects of local content. The focus of the problem in this study included: (1) the model for implementing Arabic learning at SMP Kartini Bumi, (2) supporting factors and inhibiting factors for the implementation of intensive Arabic language programs. This research uses descriptive analytical method by collecting data from interviews, observation and documentation, the data is collected and analyzed by reducing data, presenting data and drawing conclusions. From the results of the study it was found that the Arabic learning model in SMPUT Bumi Kartini used a direct learning model that is the teacher conveying the content of the subject matter in a structured and structured manner, directing the activities of the students, and maintaining the focus of academic achievement. the forms are in the form of Arabic (local content) and school extracurricular subjects. Extracurricular activities aim to support the improvement of students' ability to speak Arabic which is implemented in intensive classroom activities in Arabic, and Bilingual Club. Language intensive extracurricular activities are held every day after school, even though these activities are carried out on school boarding, but the intensive class is included in the extracurricular activities of the school. The main purpose of the direct learning model is to maximize the use of student learning time. Which in practice students practice it using Arabic in their daily lives in the boarding school environment. The supporting factor remains the implementation of intensive language classes is the existence of adequate infrastructure and students who are very enthusiastic in attending intensive language classes. While the inhibiting factor is the lack of teachers and the lack of varied learning media used in the learning process.
\end{abstract}

Keywords: learning model, Arabic, SMPUT Kartini

\begin{abstract}
ABSTRAK
Penelitian ini bertujuan untuk mendeskripsikan model pembelajaran bahasa Arab di SMPUT Bumi Kartini dalam upaya meningkatkan kemampuan siswa berbahasa Arab, selain itu penelitian ini juga berusaha memaparkan beberapa faktor yang menghambat dan faktor yang mendukung terselenggaranya program kelas intensif bahasa Arab (kegiatan ekstrakurikuler) yang dilaksanakan dilingkungan boarding school SMPUT Bumi Kartinidalam upaya meningkatkan kemampuan berbahasa Arab peserta didik selain mata pelajaran bahasa Arab yang memang
\end{abstract}


mereka dapatkan dalam pembelajaran dikelas sebagai mata pelajaran muatan lokal. Fokus masalah dalam penelitian ini meliputi: (1) model pelaksanaan pembelajaran bahasa Arab di SMPUT Bumi Kartini, (2) factor pendukung dan factor penghambat terselenggaranya program kelas intensif bahasa Arab. Penelitian ini menggunakan metode deskriptif analitis dengan cara mengumpulkan data dari wawancara, observasi serta dokumentasi, data tersebut dikumpulkan serta dianalisis dengan cara mereduksi data, menyajikan data kemudian penarikan kesimpulan. Dari hasil penelitian tersebut ditemukan bahwa model pembelajaran bahasa Arab di SMPUT Bumi Kartini menggunakan model pembelajaran langsung yaitu guru menyampaikan isi materi pelajaran dengan format dan terstruktur, mengarahkan kegiatan para peserta didik, dan mempertahankan pada fokus pencapaian akademik.Adapun dalam pembelajaran bahasa Arabnya dilaksanakan dalam dua bentuk yaitu dalam bentuk mata pelajaran bahasa Arab (muatan lokal) dan ekstrakurikuler sekolah. Kegiatan Ekstrakurikuler bertujuan untuk menunjang peningkatan kemampuan siswa untuk berbahasa Arab yang diimplementasikan dalam kegiatan kelas intensifbahasa Arab, dan Bilingual Club. Kegiatan ekstrakurikuler kelas intensif bahasa dilaksanakan setiap hari sepulang sekolah, meskipun kegiatan tersebut dilaksanakan di boarding sekolah, namun kelas intensif tersebut masuk dalam kegiatan ektrakurikuler sekolah.Tujuan utama model pembelajaran langsung adalah untuk memaksimalkan penggunaan waktu belajar peserta didik. Yang dalam prakteknya peserta didik mempraktekkannya dengan menggunakan bahasa Arab dalam kesehariannya di lingkungan boarding school. Adapun factor pendukung tetap terselenggaranya kelas intensif bahasa ialah adanya sarana prasarana yang cukup memadai dan peserta didik yang sangat antusias dalam mengikuti kelas intensif bahasa. Sedangkan factor penghambatnya ialah kurangnya tenaga guru dan kurang bervariatifnya media pembelajaran yang digunakan dalam proses pembelajaran.

Kata kunci: model pembelajaran, bahasa Arab, SMPUT Bumi Kartini 


\section{A. PENDAHULUAN}

Model pembelajaran bahasa Arab terpadu merupakan salahsatu model implementasi kurikulum yang diaplikasikan pada semua jenjang pendidikan, baik pendidikan dasar (SD/MI), pendidikan menengah pertama (SMP/MTs), dan pendidikan menengah atas (SMA/MA). Melalui model pembelajaran bahasa Arab terpadu diharapkan siswa memperoleh pengetahuan dan menguasai 4 keterampilan berbahasa arab secara utuh dan bermakna. (Trianto, 2010)

Model pembelajaran bahasa Arab terpadu merupakan bentuk pembelajaran yang sangat memperhatikan kebutuhan siswa sesuai masa perkembangannya. Pembelajaran bahasa Arab terpadu melibatkan siswa secara aktif di dalam proses pembelajarannya baik secara fisik maupun emosional siswa, sehingga dapat menerapkan perolehan belajar siswa dengan melalui pengalaman yang kongkrituntukmemecahkanmasalahdi dalam kehidupan sehari-hari (Eko Budi, 2013). Dari kesimpulan di atas menjelaskan bahwasanya pengalaman belajar siswa sangatlah penting dalam model pembelajaran bahasa Arab terpadu.

Interaksi belajar mengajar merupakan masalah yang kompleks karena melibatkan berbagai faktor yang saling terkait satu sama lain. Dari beberapa faktor yang mempengaruhi proses serta hasil interaksi belajar mengajar ada dua faktor yang menentukan yaitu faktor guru sebagai yang berperan sebagai subjek pembelajaran serta faktor peserta didik/siswa sebagai objek pembelajaran.

Dalam proses interaksi belajar mengajar berbagai potensi kognitif, afektif, dan psikomotoriksangat berpengaruh terhadap hasil. Meski demikian, pengaruh dari faktor lain tidak boleh diabaikan, semisalnya faktor media ,instrument pembelajaran, fasilitas laboratorium, manajemen sekolah,fasilitas belajar, infrastruktur sekolah, sistem pembelajaran,metode, strategi evaluasi, kurikulum, serta modelpembelajaran. Semua faktor tersebut memberikan kontribusi yang berarti dalam meningkatkan kualitas serta hasil belajar mengajar peserta didik

Selain sebagai bahasa komunikasi yang paling penting di dunia, bahasa Arab juga selalu dipakai dalam segala bentuk kegiatan atau ritual keagamaan seperti halnya dalam kegiatan shalat, berdoa, membaca al-Qur'an, khutbah serta untuk memahami ajaran agama baik dari al-Qur'an maupun hadis. Di Indonesia sendiri pembelajaran bahasa Arab sudah berkembang pesat, bahkan pembelajarannya sudah dimulai sejak anak duduk di TK sampai perkuliahan. Meskipun demikian kondisi pengajaran Bahasa Arab di sekolah maupun pesantren di Indonesia masih dihadapkan berbagai tantangan dan kendala. Tantangan dan kesulitan tersebut terjadi dikarenakan berbagai faktor, diantaranya berkaitan dengan metodologi, tenaga pengajar, media pembelajaran maupun sarana prasarana.

Program bilingual (bahasa Arab dan Inggris) telah banyak diterapkan di lembaga pendidikan sebagai program unggulan. Seperti halnya di Sekolah Menengah Pertama Unggulan Terpadu Bumi Kartini Jepara. Namun pada prakteknya, program unggulan bahasa mengalami hambatan dan tidak berjalan seimbang antara bahasa Arab dan Inggris. Mayoritas keluhan siswa adalah kesulitan dalam penggunaan bahasa Arab baik dalam hal percakapan maupun penulisan. Penguasaan dalam kedua keterampilan tersebut membutuhkan penguasaan ilmu nahwu. Oleh karena itu perlu adanya upaya membantu meningkatkan kemampuan siswa dalam menguasai ilmu tesebut. 
Penelitian ini bertujuan mendeskripsikan bagaimana model pembelajaran bahasa Arab terpadu di SMPUT Bumi Kartini, serta dampak dari penerapan model pembelajaran tersebut bagi peserta didik.

\section{B. METODE PENELITIAN}

Penelitian yang digunakan peneliti dalam penelitian ini berjenis penelitian studi kasus yaitu jenis penelitian yang difokuskan pada sebuah kasus (fenomena) yang dipahami serta dianalisis secara mendalam(Nana Syaodih,2005). Bentuk Metode penelitian ini digunakan untuk mendeskripsikan sebuah fenomena secara holistic serta komperhensif tentang munculnya gejala dan peristiwa dalam melaksanakan program model pembelajaran bahasa Arab terpadu di SMPUT BUMI KARTINI JEPARA.

\section{PEMBAHASAN}

\section{Bentuk Model Pembelajaran}

Bentuk model pembelajaran sangatlah banyak, diantara bentuk model pembelajaran ialah dengan model pembelajaran langsung, model pembelajaran berbasis masalah (PBM), model pembelajarn kontekstual, model pembelajaran Index Card Match dan Model pembelajaran kooperatif (Muhamad afandi, 2013) .

Dari sekian banyaknya model pembelajaran, SMPUT menerapkan model pembelajaran langsung dalam pembelajaran bahasa Arab. Adapun cara kerja dari model pembelajaran langsung ialah guru mentransformasikan informasi/ keterampilan secara langsung kepada peserta didik, dengan berorientasi pada tujuan dan proses pembelajaran distrukturkan oleh guru. (Depdiknas, 2010: 24). Menurut Killen, depdiknas (2010: 23) pembelajaran langsung atau biasa disebut
Direct Instruction merujuk pada teknik pembelajaran ekspositori yaitu bentuk pemindahan pengetahuan dari guru kepada muridnya secara langsung, dapat melalui ceramah, tanya jawab dan demonstrasi dengan melibatkan seluruh kelas. Pendekatan dengan model pembelajaran ini berpusat kepada guru, Guru menyampaikan isi materi pelajaran dengan format dan terstruktur, mengarahkan kegiatan para peserta didik, dan mempertahankan pada fokus pencapaian akademik. Tujuan utama pembelajaran langsung adalah untuk memaksimalkan penggunaan waktu belajar peserta didik (Depdiknas, 2010).

Model Pembelajaran Langsung memang dirancang untuk menciptakan lingkungan belajar terstruktur dan tetap berorientasi pada pencapaian akademik. Guru sebagai penyampai informasi melakukan tugasnya dengan menggunakan berbagai media. Adapun informasi yang disampaikanberupa pengetahuan prosedural yaitu pengetahuan bagaimana melaksanakan sesuatu atau bisa disebut dengan pengetahuan deklaratif ( pengetahuan tentang sesuatu berupa fakta, konsep, prinsip, generalisasi).

Model pembelajaran langsung diidentifikasi beberapa karakteristik, yaitu :

Transformasi dan keterampilan
secaralangsung
2) Pembelajaran yang berorientasi pada
tujuantertentu
3) Materi pembelajaranterstruktur
4) Lingkungan belajarterstruktur
5) Distrukturi olehguru (Depdiknas,
2010)

Kelebihan dari model pembelajaran langsung adalah sebagai berikut:

a) Dengan model pembelajaran 
secara langsung, guru dapat mengendalikan isi materi dan berbagai urutan informasi yang akan diterima siswa sehingga dapat mempertahankan fokus dari apa yang harus dicapaisiswa.

b) Model pembelajaran langsung dapat diterapkan secara efektif dalam kelas besar maupunkecil.

c) Dapat digunakan untuk menekankan beberapa poinpenting atau kesulitanyang dihadapi siswa.

d) Dapat dijadikan sebagaicara yang efektif dalam mengajarkan informasi dan pengetahuan yang faktual secara terstruktur.

e) Sebagai cara yang efektif untuk mengajarkan konsep beserta keterampilan yang eksplisit kepada siswa yang memilik prestasi tinggi ataupun rendah

f) Mampu menyampaikan informasi yang banyak hanya dengan waktu yang relatif singkat.

g) Memungkinkan guruuntuk menyampaikan ketertarikan secara pribadi tentang mata pelajaran (dengan presentasi yang antusias) sehingga dapat merangsang ketertarikan dan antusiasme siswa.

h) Dengan ceramah dapat menyampaikan informasi kepada siswa yang kurang suka membaca atau yang tidak mempunyai keterampilan untuk menyusun serta menafsirkaninformasi.

i) Secara keseluruhan, ceramah merupakan cara yang paling memungkinkan agar tercipta lingkungan yang tidak mengancam serta siswa dapat terbebas dari stress, sangat cocok bagi siswa yang pemalu dan tidak percaya diri (Sudrajat, 2011).

\section{Model Pembelajaran Bahasa Arab}

Menurut Corey, konsep pembelajaran ialah sebuah proses yang dengan sengaja lingkungan dibentuk agar dalam kondisi tertentu mampu menghasilkan respon lingkungan sengaja dibentuk agar memungkinkannya ikut serta dalam kondisi tertentu yang menghasilkan respon pada situasi tertentu (Sagala, 2010). Oleh karenanya lingkungan belajar haruslah dapat dikelola dengan baik karena pembelajaran memiliki peran yang penting dalam pendidikan.

Pembelajaran merupakansebuah kombinasi yang tersusun dari unsur manusia, fasilitas, ataupun perlengkapan yangmana prosedur antara satu dengan lainnyasaling mempengaruhi untuk mencapai tujuan (Hamalik, 2011). Pembelajaran juga dimaknai proses yang dilakukan guru dan siswa dalam belajar mengajar untuk memperoleh ilmu pengetahuan, ketrampilan, serta terjadi perubahan sikap (Dimyati,1999:157). Perbedaan yang menonjol Hamalik menitikberatkan sarana sebagai pendukung proses pembelajaran. Sedangkan Dimyati fokus pada pengetahuan dan sikap dalam proses pembelajaran tersebut.

Adapun konsep model pembelajaran ialah suatu perencanaan yang digunakan sebagai pedoman dalam merencanakan bentuk pembelajaran dikelas. Model pembelajaran sendiri haruslah mengacu pada pendekatan pembelajaran yang digunakan yaitu meliputi tujuan pengajaran, tahapan 
kegiatan pembelajaran, lingkungan pembelajaran serta bentuk pengelolaan kelas. Dengan demikian model pembelajaran dapat didefinisikan sebagai prosedur atau pola yang dengan sistematis digunakan sebagai pedoman dalam mencapai tujuan pembelajaran yang didalamnya terdapat strategi, teknik, metode, media, bahan serta alat dalam penilaian pembelajaran.

Model pembelajaran bahasa Arab yang berada di lingkungan SMPUT Bumi Kartini dilaksanakan dalam dua bentuk yaitu dalam bentuk mata pelajaran bahasa Arab (muatan lokal) dan ekstrakurikuler sekolah. Adapun kegiatan Ekstrakurikuler yang menunjang peningkatan kemampuan siswa untuk berbahasa Arab terdapat dalam kegiatan kelas intensifbahasa Arab, bahasa inggris, dan Bilingual Club. Kegiatan ekstrakurikuler kelas intensif bahasa dilaksanakan setiap hari sepulang sekolah, meskipun kegiatan tersebut dilaksanakan di boarding sekolah, namun kelas intensif tersebut masuk dalam kegiatan ektrakurikuler sekolah.

\section{Profil SMPUT Bumi Kartini}

Sekolah Menengah Pertama Unggulan Terpadu (SMPUT) Bumi KartiniJepara adalah salah satu sekolah swasta di Jepara yang terintegrasi dengan boarding. Berada di bawah naungan yayasan Bumi Kartini. Yangmana yayasannya membawahi beberapa lembaga pendidikan. Mulai dari Pendidikan Anak Usia Dini yang baru saja dibuka tahun ajaran 2018/2019, kemudian Sekolah Dasar Unggulan Terpadu (SDUT), dan jugaBoarding School Bumi Kartini. Adapun SMPUT Bumi Kartini baru mulai dibuka pada tahun ajaran 2017/2018, yang dikepalai oleh Ibu Siti Mardliyah, M.Pd..

Gedung SMPUT Bumi Kartini masih berada satu lokasi dengan Sekolah
Dasar Unggulan Terpadu (SDUT) Bumi Kartini. Jumlah peserta didik SMPUT ada 25 anak, karena baru memiliki satu kelas VII. Peserta didik SMPUT tidak hanya dari alumni SDUT Bumi Kartini. Ada beberapa peserta didik dari sekolah lain di Jepara, serta ada pula lulusan sekolah luar kota Jepara. Semua peserta didik SMPUT diwajibkan tinggal di boarding school Bumi Kartini. Hal itu untuk mendukung program-program unggulan sekolah.

Program unggulan SMPUT Bumi Kartini adalah program tahfidh al-Qur'an dan bahasa asing. Sekolah ini termasuk rintisan lembaga yang menerapkan program bilingual. Ada beberapa waktu dimana semua anak beserta pendidik dianjurkan menggunakan bahasa Arab dan Inggris dalam berkomunikasi. Maka ada program khusus dalam hal peningkatan bahasa asing, seperti kelas intensive bahasa Arab, bahasa inggris, dan Bilingual Club.

\section{Program Pembelajaran Bahasa Arab di SMPUT}

Pembelajaran intensive bahasa Arab diarahkan untuk mendorong, membimbing, mengembangkan serta membina kemampuan siswa untuk menumbuhkan sikap positif pada bahasa Arab baik secara Reseptif maupun Produktif dengan intensive. Yang dimaksud dari kemampuan Resertif ialah kemampuan yang digunakan untuk memahami pembicaraan orang dan memahami bacaan. Sedangkan kemampuan Produktif adalah kemampuan menggunakan bahasa yang dipakai sebagai alat komunikasi tulis maupun lisan. Pembelajaran bahasa Arab ini dilaksanakan secara intensive setiap hari diluar jam sekolah. Kemampuan berbahasa Arab peserta didik serta sikap positif atas bahasa Arab tersebut sangatlah penting untuk membantu memahami 
sumber ajaran Islam, bahasa Arab sendiri saat ini telah menjadi salah satu bahasa Internasional.

Oleh karenanya bahasa Arab di SMPUT dipersiapkan guna pencapaian kompetensi dasar berbahasa, dengan mengutamakan empat keterampilan dalam berbahasa yaitu menyimak, berbicara, membaca dan menulis. Pada dasarnya pembelajaran bahasa asing pada tingkat pendidikan dasar dititik beratkan pada kecakapan berbicara dan menyimakyangmana kedua hal tersebut adalah landasan dalam berbahasa. Sedangkan pada tingkat pendidikan menengah keempat kecakapan tersebut di atas mulai diajarkan secaraberimbang. Pada tingkat pendidikan lanjutdikonsentrasikan pada kecakapan siswa dalam membaca dan menulis, yangmana peserta didik diharapkan dapat mengakses berbagai referensi bahasa Arab.

Dilaksanakannya pembelajaran bahasa arab intensif di SMPUT sangat baik untuk mengembangkan kemampuan peserta didik dalam berkomunikasi dengan bahasa Arab, yaitu dengan membiasakan peserta didik berkomunikasi di dalam kelas intensive bahasa dan di dalam boarding dengan menggunakan bahasa Arab dalam dua minggu dan dua minggu setelahnya menggunakan bahasa Inggris. Kemudian dengan menumbuhkan kesadaran kepada peserta didik akan pentingnya bahasa Arab sebagai salah satu bahasa asing yang telah menjadi alat utama dalam belajar terutama kaitannya atas sumber-sumber ajaran Islam. Dan menumbuhkan pemahaman bahwa antara bahasa dan budaya merupakan dua hal yang dipakai untuk memperluas cakrawala pengetahuan.

Tanda Keberhasilan dalam mencapai beberapa Kemahiran berbahasa Arab di antaranya:
1. Kemahiran istima' (menyimak)

Skill menyimak dapat diraih dengan memperbanyak latihan mendengarkan percakapan berbahasa Arab, dapat langsung dari native speaker (melalui rekaman) dengan cara memahami maksud atau arti dari apa yang didengarkannya.

2. Kemahiran kalam (berbicara) Speaking skill atau kemahiran dalam berbicara merupakan hal yang cukup rumit, hal ini dikarenakan erat kaitannya dengan masalah berfikir yaitu ketika berbicara haruslah berfikir dulu bagaimana pola bahasa yang akan diucapkan. Dengan demikian penguasaan atas perbendaharaan kata sangat diperlukan.

3. Kemahiran Qiro'ah (membaca)

Dalam kemahiran ini erat kaitannya dengan mengenali dua hal yaitu mengenali simbul yang tertulis dan memahami isi dari teks. Dalam aktifitas membaca selalu menyediakan input bahasa yang sama seperti halnya menyimak. Membaca memiliki beberapa kelebihan dari pada menyimak dalam hal perbendaraan kata yang lebih akurat, pembaca bersifat otonom yang dapat berhubungan langsung dengan majalah, buku ataupun surat kabar yang berbahasa Arab, dengan cara seperti itu akan di dapatkan kosakata baru dan berbagai bentuk bahasa dengan jumlah yang banyak. Dengan demikian menunjukkan bahwasanya pembiasaan agar siswa mau membaca perlu memperoleh perhatian yang serius.

4. Kemahiran dalam kitabah (menulis)

Kemahiran ini menyangkut tiga hal yaitu kemahiran dalam membuat alphabet dengan menyatakan bunyi yang berbedabeda antar bahasa, kemudian kemahiran mengeja dengan memodifikasi kalimat dengan mengubah kalimat dengan unsur 
lain dengan menyempurnakan kalimat yang belum selesei dengan mengubah kalimat pasif menjadi aktif atau sebaliknya, dan yang terakhir ialah kemahiran dalam mengungkapkan perasaan, pikiran melalui tulisan yang lazim disebut dengan komposisi, dengan sering melakukan latihan-latihan, yaitu: merangkum bacaan dengan menceritakan kembali namun menggunakan bahasa dari peserta didik sendiri, kemudian menceritakan gambar yang dilihat ataupun pekerjaan yang dilakukan seharihari dengan bahasa peserta didik itu sendiri, mendeskripsikan apa yang dilihat, serta menceritakan apa yang biasa dilakukan dengan menggunakan bahasa peserta didik itu sendiri (Rohmalina, 2014)

Pemilihan atas model pembelajaran yang dipilih sangatlah mempengaruhi hasil belajar siswa, oleh karenanya dalam dunia pendidikan berkembang berbagai model pembelajaran agar tujuan kompetensi belajar dapat tercapai secara cepat, efektif dan efisien (Jumanta, 2016).

\section{Faktor Pendukung dan Penghambat Program Kelas Bahasa Arab Intensif di} SMPUT Bumi Kartini

Dalam setiap pembelajaran apabila didukung oleh faktor pendukung maka pembelajaran tersebut akan dapat berjalan secara efektif dan membantu peserta didik dalam mempercepat pemahamannya, namun sebalikanya, apabila dalam proses pembelajaran tersebut terdapat hal-hal yang menghambat maka akan menjadikan proses pembelajaran tersebut akan tersendat dan mengelami perlambatan karena faktor-faktor penghambat tersebut tentunya dapat mengganggu pemahaman peserta didik terhadap bahasa Arab.
Berdasarkan hasil observasi, wawancara dan pengumpulan data yang telah dilakukan oleh peneliti, dapat kami tunjukkan bahwasanya pelaksanaan program kelas intensif ini memberi dampak yang positif dalam beberapa hal, salah satunya meningkatnya motivasi siswa dalam belajar bahasa Arab dan memberi ruang lebih pada peserta didik untuk belajar bahasa Arab.

Berikut beberapa faktor yang mendukung kelancaran proses pembelajaran kelas bahasa Arab intensif di SMPUT Bumi Kartini

a. Sarana dan prasarana yang cukup memadai, tidak dapat dipungkiri bahwasanya kedua hal tersebut erat kaitannya dalam upaya meningkatkan kualitas belajar siswa. Selain kemampuan guru dalam penyelenggaraan kegiatan pembelajaran seorang guru juga sangat membutuhkan sarana pembelajaran yang dapat menunjang kegiatan pembelajarannya, selain itu bagi guru adanya fasilitas sarana dan prasarana akan menjadikan pembelajaran lebih bervariatif, menarik dan lebih bermakna.Tidak seluruhnya peserta didik mempunyai tingkat kecerdasan yang tinggi sehingga sangatlah penting dalam penggunaan sarana dan prasarana pembelajarn dapat membantu peserta didik, terutama yange memiliki kelemahan dalam keikutsertaannya dalam kegiatan pembelajaran.

b. Antusiasnya peserta didik dalam mengikuti pembelajaran di kelas bahasa Arab intensif, hal ini 
dikarenakan beberapa hal, diantaranya bahasa Arab telah mereka kenal sejak kecil yaitu dalam rutinitas keagamaan semisal doa, sholat, mengaji, maupun dalam ibadah-ibadah yang lain. Dan beberapa diantara peserta didik telah mengenal kebudayaan bangsa Arab.

Selain adanya faktor pendukung, dalam proses pembelajaran kelas intensif bahasa di SMPUT Bumi Kartini Jepara juga terdapat beberapa faktor penghambat, berikut beberapa faktor yang menghambat proses pembelajaran bahasa Arab:

a. Kurangnya tenaga guru, tentu dapat menghambat proses belajar mengajar, pembelajaran yang berlangsung akan kurang optimal dikarenakan kurangnya tenaga pendidik. Bahkan belum ada guru bahasa Arab yang khusus bertanggung jawab di boarding SMPUT Bumi Kartini. Sehingga dalam dua tahun ini pengasuh boarding di SMPUT Bumi Kartini juga merangkap menjadi guru bahasa Arab.

b. Kurang bervariatifnya media pembelajaran di kelas intensif bahasa Arab, tujuan utama dari media pembelajaran ialah agar pesan ataupun informasi yang disampaikan oleh guru dapat diterima atau diserap secara maksimal oleh peserta didik. Dan dengan adanya media pembelajaran informasi lebih cepat dan lebih mudah diproses oleh peserta didik tanpa perlu melalui proses yang panjang dan tentunya proses tersebut akan menjadikan peserta diidk menjadi bosan dan jenuh. Dengan poinpoin tersebut menjelaskan bahwa penggunaan media sangatlah membantu guru untuk mempermudah dalam menyampaikan materi pembelajaran (Imam Makruf, 2009). Hal ini dikarenakan guru tidak perlu mengulang-ulang dalam menjelaskan isimaterinya. Selain memperingan guru, media pembelajaran juga dapat mempermudah peserta didik dalam mengingat serta memahami isi dari materi yang diajarkan.

\section{PENUTUP}

Program bilingual (bahasa Arab dan Inggris) telah banyak diterapkan di lembaga pendidikan sebagai program unggulan Model pembelajaran bahasa Arab yang berada di lingkungan SMPUT Bumi Kartini dilaksanakan dalam dua bentuk yaitu dalam bentuk mata pelajaran bahasa Arab (muatan lokal) dan ekstrakurikuler sekolah. Adapun kegiatan Ekstrakurikuler yang menunjang peningkatan kemampuan siswa untuk berbahasa Arab terdapat dalam kegiatan kelas intensifbahasa Arab, bahasa inggris, dan Bilingual Club. Kegiatan ekstrakurikuler kelas intensif bahasa dilaksanakan setiap hari sepulang sekolah, meskipun kegiatan tersebut dilaksanakan di boarding sekolah, namun kelas intensif tersebut masuk dalam kegiatan ektrakurikuler sekolah.

Dilaksanakannya pembelajaran bahasa arab intensif di SMPUT sangat baik untuk mengembangkan kemampuan peserta didik dalam berkomunikasi dengan bahasa Arab, yaitu dengan membiasakan peserta didik berkomunikasi di dalam kelas intensive bahasa dan di dalam boarding dengan menggunakan bahasa Arab dalam dua minggu dan dua minggu setelahnya menggunakan bahasa Inggris. Namun dalam 
pelaksanaannya tentu ada beberapa factor yang mendukung terselenggaranya program tersebut secara maksimal namun juga terdapat kendala atau hambatan dalam pelaksanaannya.

\section{DAFTAR PUSTAKA}

Afandi, Muhammad, dkk. 2013. Model dan Metode Pembelajaran di Sekolah. Semarang: Sultan Agung Press.

Depdiknas, 2010. Evaluasi Pendidikan. Jakarta: Rineka Cipta

Dimyati.1999. Belajar dan Pembelajaran. Jakarta: Rineka Cipta.

Hamalik, Oemar. 2011. Kurikulum dan Pembelajaran. Jakarta: Bumi Aksara.

Hamdayama, Jumanta. 2016. Metodologi Pengajaran. Jakarta: PT. Bumi Aksara.
Imam Makruf, 2009. Strategi Pembelajaran Bahasa Arab. Semarang: Needs Press.

Ras Ekoo Budi Santoso. 2011. "Model ... http:/ / ras-

elo.blogspot.com/2011/05/modelpembelajaran-example-noneexample.html.

Sukmadinata, Nana Syaodih. 2005. Landasan Psikologi Proses Pendidikan. Bandung: PT Rosda Karya.

Sudrajat,Akhmad. 2011. Pengertian Pendekatan, Strategi, Metode, Teknik dan. Model Pembelajaran.Bandung: Sinar Baru Algensindo.

Sagala, Syaiful. 2010. Konsep dan Makna Pembelajaran. Bandung: Alfabeta Trianto, 2010. Model Pembelajaran Terpadu. Jakarta: Bumi Aksara. Trianto. 2009 Wahab, Rohmalina. (2015). Psikologi Belajar. Jakarta: RajawaliPers. 